\title{
Исследование комбинационного рассеяния света графеном с нанометровым пространственным разрешением
}

\author{
Н. Н. Курусь ${ }^{1}$, И. А. Милёхинн ${ }^{2}$ Н.А. Небогатикова ${ }^{1}$, И.В. Антонова ${ }^{1,3}$, Е.Е. Родякина ${ }^{1,3}$, \\ А.Г. Милёхин ${ }^{1}$, А.В. Латышев ${ }^{1,3}$ \\ ${ }^{1}$ Институт физики полупроводников им. А.В. Ржанова СО РАН, Новосибирск, \\ 630090, Лаврентьева, 13 \\ ${ }^{2}$ Semiconductor Physics, Chemnitz University of Technology, D-09107 Chemnitz, Germany. \\ ${ }^{3}$ НГУ, Новосибирск, 630090, Пирогова, 1
}

DOI 10.34077/RCSP2021-66

Методы оптической спектроскопии традиционно являются эффективным неразрушающим инструментом анализа элементного состава и структуры вещества. При переходе к нанометровым масштабам исследуемых объектов существенно снижается их оптический отклик на воздействие лазерного излучения. В этой связи одной из центральных задач становится разработка методов усиления детектируемого сигнала. Использование наноструктурированных металлических подложек позволяет добиться гигантского усиления сигнала КРС (ГКРС) вследствие явления локализованного плазмонного резонанса. Подобные структуры широко применяются в исследовании ГКРС органическими молекулами и полупроводниковыми нанокристаллами $[1,3]$. Частным случаем ГКРС является метод усиленного зондом комбинационного рассеяния света (с англ. TERS- Tip Enhanced Raman Scattering), в основе которого лежит усиление эмиссии света плазмоном, локализованным в острие металлизированного зонда атомно-силового микроскопа (ACM). Данный подход позволяет записывать колебательный спектр вещества с нанометровым пространственным разрешением. Исследование спектра КРС материалом, помещенным в зазор между металлическим элементом плазмонной подложки и острием металлизированного зонда, позволяет добиться гораздо большего усиления эмиссии света за счёт реализации режима щелевого плазмона (от. Англ. «Gap-mode»). В то же время, число работ, посвященных исследованию плазмон-усиленного КРС графеном и графеноподобными материалами, весьма ограничено. Двумерные материалы, как правило, применятся в качестве функционального элемента гибридных подложек, например, для сглаживания рельефа металлических структур и усиления оптического отклика аналита $[4,5]$. При этом можно ожидать, что исследования эффектов ГКРС графеном и его производными позволят глубже понять механизмы плазмонного усиления оптического отклика.

Данная работа посвящена исследованию в режиме щелевого плазмона с нанометровым пространственным разрешением КРС оптическими колебаниями пленки мультиграфена, расположенного на подложке в виде периодического массива золотых нанодисков.

Получено усиление (К $~ 100)$ основных колебательных мод мультиграфена, наблюдаемых в области золотых нанодисков. Известно, что колебательный спектр графена изменяется при отклонении кристаллической структуры от идеальной. В данной работе показано, что метод усиленного зондом комбинационного рассеяния света чувствителен к механическим напряжениям в графене. Благодаря нанометровому пространственному разрешению записана карта КРС, визуализирующая складки в графене, лежащем на массиве золотых нанодисков. Полученные результаты свидетельствуют о перспективности данного метода в исследовании локальных дефектов в структуре двумерных графеноподобных материалов.

Работа выполнена при финансовой поддержке РФФИ (проект № 20-52-04009).

\section{Литература}

[1] Набиев И. Р., Ефремов Р. Г., Чуманов Г. Д., УФН, 154(3), 459 (1988).

[2] Kneipp K. et al. PRL 78(9), 1667 (1997).

[3] Milekhin, A. G. et al. Beilstein J. Nanotechnol. 6, 749-754 (2015).

[4] Weigao, et al.Proceedings of the National Academy of Sciences 109(24), 9281-9286 (2012).

[5] Xu,Weigao et al. Small 9(8), 1206-1224 (2013). 